\title{
James de S Wijeyeratne: a musical doctor
}

Dr James de Silva Wijeyeratne $(1889$ - 1943) was a medical practitioner in Negombo who was well-known as a writer on music in the 1920s and 30s. He was also Ceylon correspondent to a leading British musical journal of that time, The Musical Standard (which ended its 71-year old existence in 1933). He was also music critic to the Ceylon Independent and later to the Ceylon Morning Leader.

Dr Wijeyeratne wrote several books. Two of the books are specifically on music. His first book was Musical moments: a series of short essays (London: Reeves,? 1924). His second book was a novel. The exiles: a tale of Ceylon student life in London (The Ceylon Morning Leader Press, 1926), dedicated to Miss Gladys de Soysa, his future wife. Even this book has two chapters devoted mainly to music, entitled "An evening with Chopin" and "A Rachmaninov recital". One of the characters in the novel is Dr Max van Linder, a Ceylonese medical doctor who had qualified at University College Hospital, and was doing postgraduate studies at the London School of Tropical Medicine. A gentle and thoughtful character with strong musical interests, Dr van Linder seems like a self-protrait of the author. Dr. Wijeyeratne's third book was Studies on musical appreciation: with special reference to western music in Ceylon (London: Reeves,? 1927). Musical moments and Studies on musical appreciation were approved by the Education Department in 1934 for use in school libraries. There is also a book called Daughter of Lanka: a tale of modern Ceylon, in which the principal character is a London-returned Dr Raymond Piyasinghe. And a fifth book is Ummada-Citta: a historical romance of ancient Ceylon (Negombo, 1933).

Dr James de S Wijeyeratne, b. 12 Oct. 1889, was of upper middle class, strengthened by his marriage to Gladys, daughter of Mr and Mrs E L F de Soysa. Mr Soysa was a son of Charles de Soysa and Lady de Soysa. Wijeyeratne became a medical doctor, with medical studies which began in Colombo and were completed in University College, London. He took the diplomas of MRCS LRCP, returned to Ceylon in 1918, and went into private practice in Negombo for the next three-and-a-half years. He went back to the UK in 1922 as London correspondent to the Ceylon Morning Leader and simultaneously to get his University degree of MBBS in 1923, preceded shortly before that by the certificate of the London School of Tropical Medicine. In January 1924 he obtained the Diploma in Tropical Medicine and Hygiene.

The Musical Standard of December 1, 1923, had a column entitled "A Brilliant Personality", part of which I shall quote:

"From time to time readers of The Musical Standard will have read some very interesting articles on music, kindly contributed to our columns by $\mathrm{Dr} \mathrm{J}$ de $\mathrm{S}$ Wijeyeratne. We feel sure many will like to learn some details of the career of this dual personality... Dr Wijeyeratne is a doctor in the medical sense of the title...Now, he said in the course of an interview,

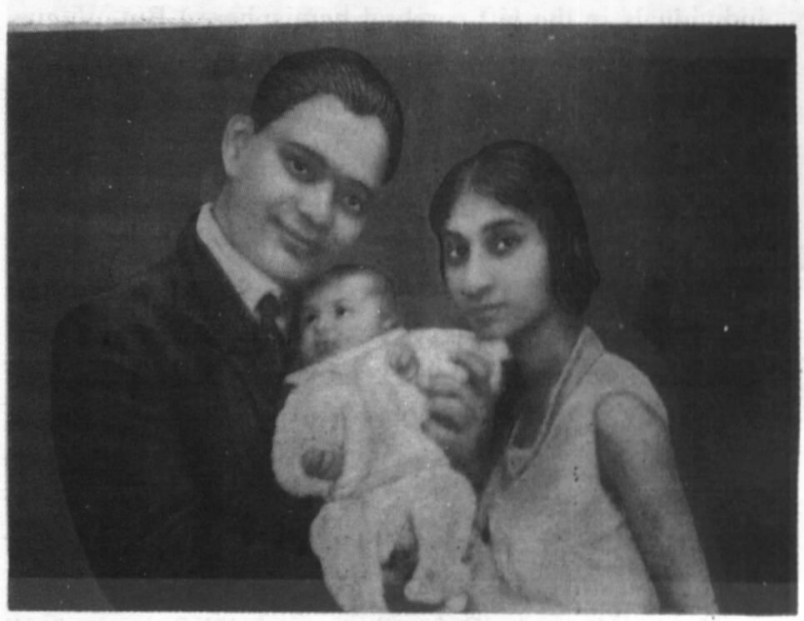

1). Jume's de S Wijeyeratne, his wife Gladys and infant daughter Neela.

\begin{abstract}
"You might perhaps wish to know how I acquired my knowledge of music. Music has always been my great hobby, although according to some of my friends, music is my vocation and medicine my hobby. When I first came to London, I took lessons in singing and in pianoforte-playing; but working for the most searching medical degree in the world I naturally could not find time to devote my serious attention to these subjects; however, my great ambition was to qualify myself as a musical critic, and I set to work by attending every important opera, concert and recital held in London. Moreover, I have gone through almost the whole of a musical library of about five hundred volumes that I had collected.
\end{abstract}

"My interest in Oriental music originated through your kind invitation to contribute articles to The Musical Standard on the music of Ceylon, and you will be pleased to learn that I am already half through my work on 'Music in ancient and modern Ceylon'. I also hope to bring out my musical essays in bookform early next year." (The book he was referring to is Musical moments, which would therefore give its date as 1924.)

Musical moments has a chapter on "Diseases of the musical language" in which he gives a short account of amusia (loss of musical ability), hypermusia (excessive reaction to music, such as fainting) and paramusia (musical perceptions aroused only in parallel with other sensations such as colour). Amusia is divided, as with aphasia (loss of speech and/or writing), into sensory amusia (which is in turn subdivided into "musical deafness" and "inability to read music") and motor amusia (subdivided into "loss of singing power, "loss of writing power" and loss of power of instrumental execution"). He subscribes to then-current hypothesis that the brain centres for these various musical functions are located in special places within those for spoken and written language. (Today's hypotheses locate 
many important musical functions in the right cerebral hemisphere while language functions are located in most individuals in the left cerebral hemisphere.) But Wijeyeratne is scientifically quite aware that there is much more to be learnt about music and brain function.

"It is but fair to add", he writes, "that the theory of localisation is only generally, but not universally accepted...It is to be hoped that in spite of the difficulty that the subject presents, we shall know more anon." He gives strikingly relevant observation from personal experience. "The writer himself can certify to the fact that a high development of the musical faculty is not necessarily dependent on the possession of even ordinary intelligence". In the case of a friend of his who was subject to epilepsy from infancy, an almost idiotic standard of intelligence carried with it as a blessing, an instinct for music amounting to the marvellous. "His power of reading musical notation was very deficient, but he possessed an extraordinarily acute and accurate ear for music, as well as a good taste and a memory, quite the best in the writer's experience. This is evidence, it may be taken, for a separate location of the musical faculty."

After his return home he set up in private practice in Negombo from 1927. He sang with a tenor voice. There was a daily hour of music, including singing, at his home preceding dinner.

He died in 1943 at age 54 of a cardiac illness. He had often expressed the wish to hear the Bach-Gounod "Ave Maria" on his death-bed.

\section{Acknowledgements}

Wijeyeratne had three daughters, and it is from one of them, Mrs Neela Siromi Therese Hulugalle, that I obtained much information and material relating to her father. I acknowledge my debt to her, and also to the bibliographer, Mr Ian Goonetileke. Mr Lylie Godridge kindly lent me his copies of the two rare music books for study.

V Basnayake, Professor Emeritus, University of Peradeniya. 